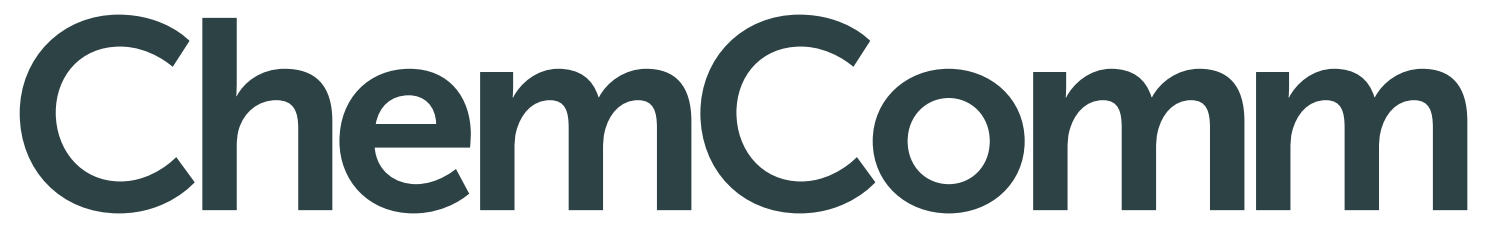

Chemical Communications www.rsc.org/chemcomm
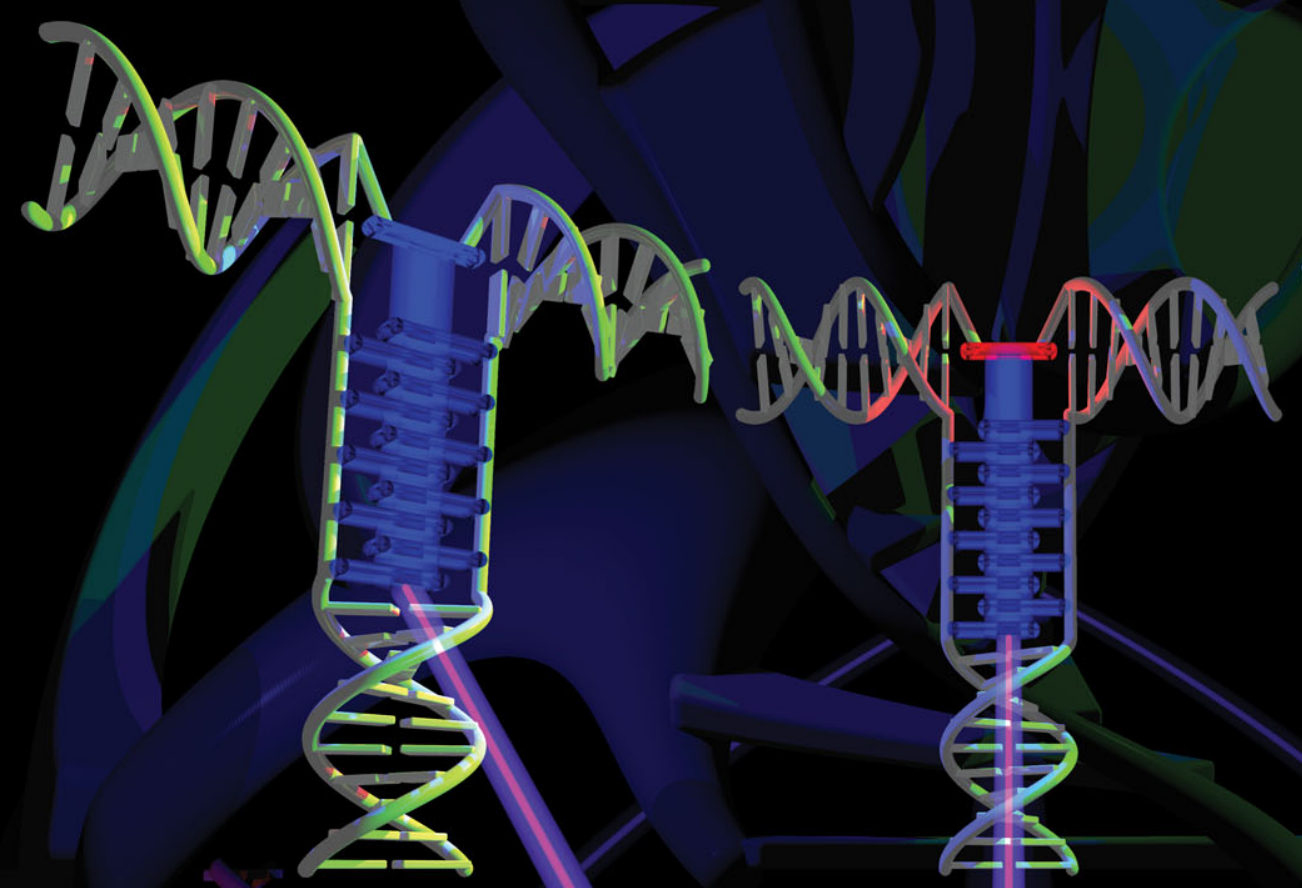

ISSN 1359-7345
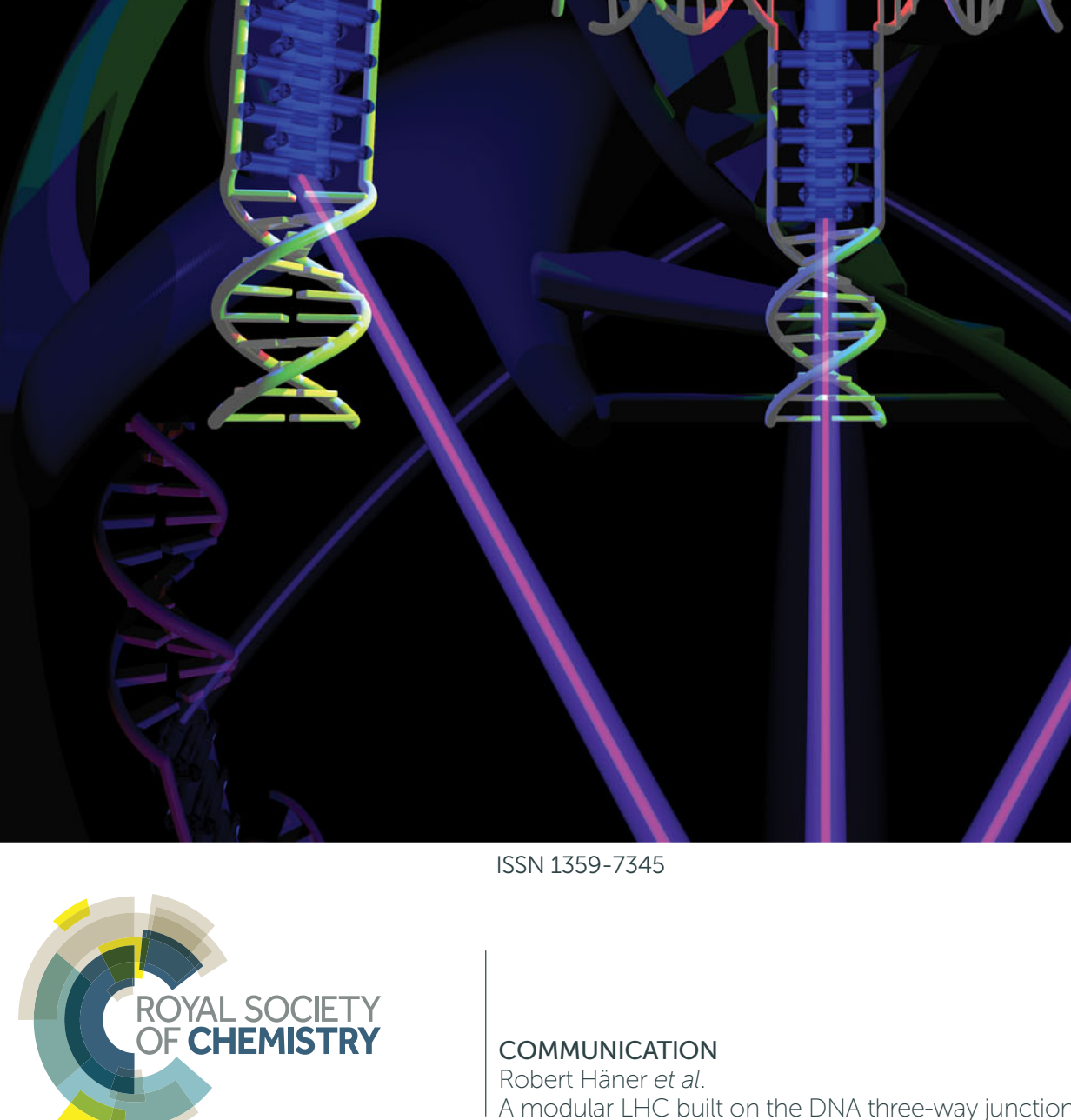


\section{A modular LHC built on the DNA three-way junction $\dagger$}

Cite this: Chem. Commun., 2014, 50, 159

Received 30th September 2013, Accepted 17th October 2013

DOI: $10.1039 / c 3 c c 47490 a$

www.rsc.org/chemcomm

\author{
Markus Probst, Simon M. Langenegger and Robert Häner*
}

\begin{abstract}
A light-harvesting complex composed of a $\pi$-stacked multichromophoric array in a DNA three-way junction is described. The modular design allows for a ready exchange of non-covalently attached energy acceptors.
\end{abstract}

In attempts to mimic the naturally occurring process of light harvesting and energy transfer in green plants, ${ }^{1-5}$ scientists are developing artificial systems ${ }^{6-17}$ that allow an efficient transfer of absorbed photons to a collection centre. A key aspect in all efforts is the proper arrangement of suitable chromophores. The field of DNA nano-architectures has received wide attention over the past years. The DNA double helix serves as a scaffold for the controlled arrangement of functional molecules, ${ }^{18-23}$ including a wide range of different chromophores. ${ }^{24-32}$ Also the DNA three-way junction ${ }^{33}$ has been exploited for this purpose. ${ }^{34-42}$ Recently, several DNAbased light-harvesting antenna systems have been reported. ${ }^{43-51}$ Here, we describe the use of the DNA three-way junction (3WJ) as a versatile scaffold for the modular construction of an artificial light harvesting complex (LHC).

The architecture of the $3 \mathrm{WJ}$, its sequences and the corresponding building blocks are shown in Scheme 1. The phenanthrene (P), ${ }^{52}$ pyrene ( $\mathbf{S}$ and $\mathbf{X})^{53,54}$ perylenediimide $(\mathbf{E}),^{55}$ and the commercially available cyanine (Cy) phosphoramidite building blocks were incorporated into the oligomers by automated oligonucleotide synthesis. All oligomers were purified by reverse phase HPLC and analysed by LC-MS (see ESI + ). In $3 \mathbf{W J}-2,-3,-4$ and -5 , the LHC is composed of a phenanthrene (P) stack, the light absorbing antenna (strands $\mathbf{a}$ and $\mathbf{b}$ ), and an exchangeable acceptor chromophore (strands $\mathbf{d}-\mathbf{g}$ ). $\mathbf{3 W J}-\mathbf{1}$ serves as a control bearing no acceptor dye in the third strand (c). Formation of the $3 \mathrm{WJs}$ was demonstrated by polyacrylamide gel electrophoresis (ESI $\dagger$ ). Thermal denaturation experiments showed a single transition for all $3 \mathrm{WJ}$ s. Melting temperature $\left(T_{\mathrm{m}}\right)$ values ranging from 57-63 ${ }^{\circ} \mathrm{C}$ are listed in Table 1 . UV/Vis spectra of the different 3WJs (Fig. 1) reveal the following long-wavelength absorptions of the

Department of Chemistry and Biochemistry, University of Bern, Freiestrasse 3, CH-3012 Bern, Switzerland. E-mail: robert.haener@dcb.unibe.ch; Tel: +41316314382 $\dagger$ Electronic supplementary information (ESI) available: Synthetic and analytical details; spectroscopic data. See DOI: 10.1039/c3cc47490a

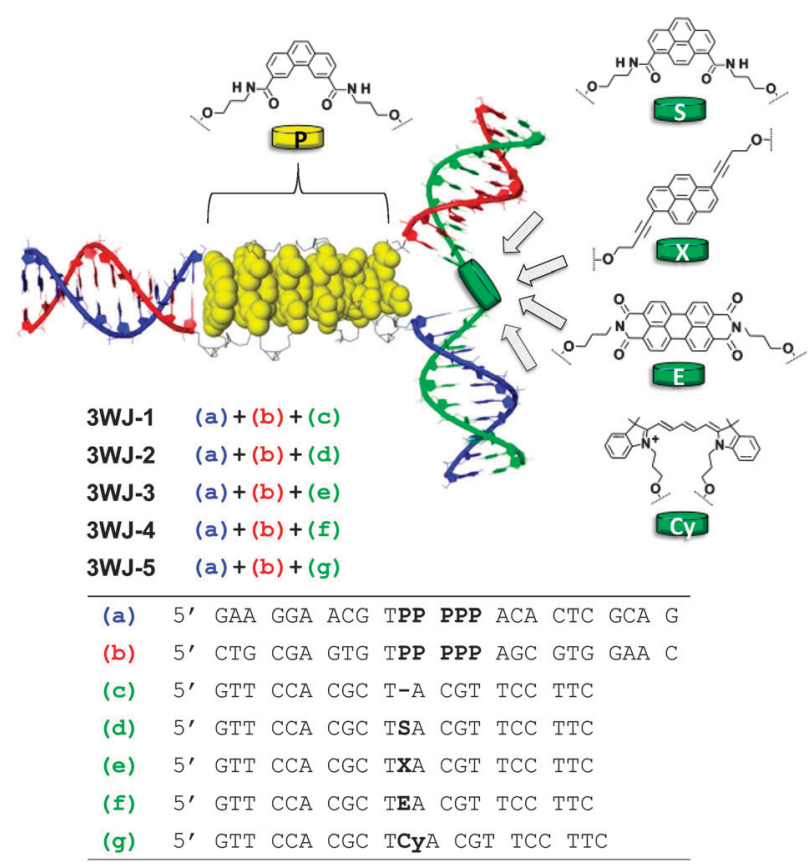

Scheme 1 Schematic illustration of the light harvesting $3 \mathrm{WJ}$, the chromophores used and the corresponding sequences.

Table $1 T_{m}$ values and fluorescence quantum yields $\left(\Phi_{\mathrm{F}}\right)^{a}$ of $3 \mathrm{WJs}{ }^{b}$

\begin{tabular}{llllll}
\hline & $3 \mathbf{W J}-1$ & $3 \mathbf{W J}-2$ & $\mathbf{3 W J}-\mathbf{3}$ & $\mathbf{3 W J - 4}$ & $\mathbf{3 W J - 5}$ \\
\hline Acceptor & - & $\mathbf{S}$ & $\mathbf{X}$ & $\mathbf{E}$ & $\mathbf{C y}$ \\
$T_{\mathrm{m}}\left({ }^{\circ} \mathrm{C}\right)$ & 57 & 59 & 58 & 63 & 59 \\
$\Phi_{\mathrm{F}}{ }^{c}$ & 0.10 & 0.21 & 0.32 & 0.02 & $0.06^{d}$
\end{tabular}

${ }^{a}$ Standard: 2-aminopyridine; for details see ESI. ${ }^{b}$ Conditions as in Fig. $1{ }^{c}$ Phenanthrene excitation $(320 \mathrm{~nm}) .{ }^{d}$ Total $\Phi_{\mathrm{F}}(1.5 \%$ from phenanthrene and $4.9 \%$ from $\mathrm{Cy}$ emission).

various chromophores: $\mathbf{P}\left(\lambda_{\max }=316 \mathrm{~nm}\right) ; \mathbf{S}\left(\lambda_{\max }=353 \mathrm{~nm}\right) ; \mathbf{X}\left(\lambda_{\max }=\right.$ $391 \mathrm{~nm}) ; \mathbf{E}\left(\lambda_{\max }=561 \mathrm{~nm}\right)$; and $\mathbf{C y}\left(\lambda_{\max }=652 \mathrm{~nm}\right)$.

The effectiveness of the 3WJs as LHCs was investigated by fluorescence spectroscopy. Fig. 2 shows the emission spectra of $3 \mathbf{W J}-\mathbf{1}$ to $3 \mathbf{W J}-4$ after excitation of phenanthrene at $320 \mathrm{~nm}$. $3 \mathbf{W J}-2$ and $3 \mathbf{W J}-3$, both of which contain a pyrene derivative as acceptor, exhibit strong 


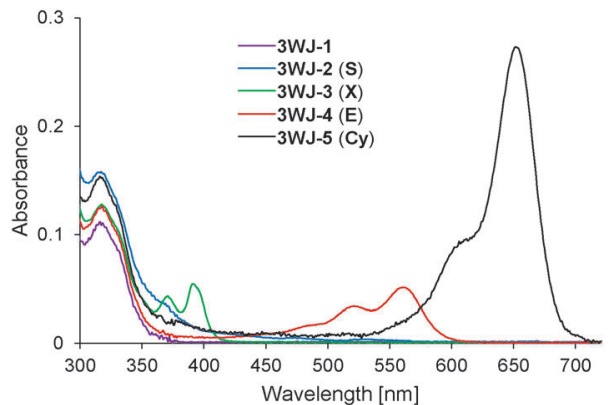

Fig. 1 UV/Vis spectra of the investigated three-way junctions. Conditions: $1 \mu \mathrm{M}$ single strand, $100 \mathrm{mM} \mathrm{NaCl}, 10 \mathrm{mM}$ sodium phosphate buffer, $\mathrm{pH}$ 7.0; acceptors are given in brackets.

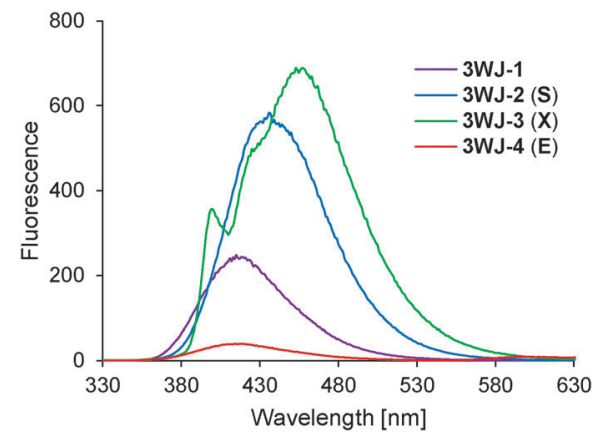

Fig. 2 Fluorescence emission spectra of 3 WJ-1, 3WJ-2, 3WJ-3 and 3WJ-4 Conditions: see Fig. 1; $\lambda_{\text {ex: }} 320$ nm; ex./em. slit: 5 nm.

exciplex emission $\left(\lambda_{\max }=435\right.$ and $455 \mathrm{~nm}$, respectively $\left.{ }^{56}\right)$. This is in agreement with the observation made previously with a duplex containing a phenanthrene antenna with a covalently attached pyrene (S). ${ }^{46}$ In the present case, however, the acceptor dye is brought into proximity of the phenanthrene antenna in a non-covalent fashion.

A quantum yield of 0.21 (Table 1) is obtained for $3 \mathbf{W J}-2$. Similar results are obtained for $\mathbf{3} \mathbf{W J}-\mathbf{3}$. However, some pyrene monomer fluorescence (peak at $400 \mathrm{~nm}$ and shoulder at around $425 \mathrm{~nm}$ ) is present in addition to the exciplex emission. The total quantum yield of 3WJ-3 with 1,6-dialkynylpyrene as the acceptor dye is 0.32 .

Irradiation of the control $\mathbf{3 W J}-\mathbf{1}$, which contains the phenanthrene stack but no acceptor chromophore, at $320 \mathrm{~nm}$ results in a broad, unstructured emission band centred around $415 \mathrm{~nm}$, which is assigned to phenanthrene excimer fluorescence. ${ }^{57-60} \Phi_{\mathrm{F}}$ for $\mathbf{3 W J}-\mathbf{1}$ was 0.10 (Table 1). This is considerably less than the values found for $3 \mathbf{W J}-2$ and $-\mathbf{3}(0.21$ and 0.32$)$ that contain a terminal pyrene chromophore.

In three-way junction $\mathbf{3 W J}-\mathbf{4}$, a perylenediimide unit is used in strand $\mathbf{c}$. This chromophore quenches the phenanthrene excimer fluorescence to a considerable extent $\left(\Phi_{\mathrm{F}} 0.02\right)$. The quenching effect $^{61,62}$ is strong, but not as pronounced as in the case of pyrene excimer quenching by the same perylenediimide derivative. ${ }^{37,63}$ The reduced effect can be rationalized by a smaller spectral overlap in the present case (phenanthrene-perylenediimide) than between pyrene and perylenediimide. ${ }^{63}$

The emission spectra obtained by direct excitation of the twopyrene acceptor dyes ( $\mathbf{S}$ or $\mathbf{X})$ are shown in Fig. 3. Excitation was carried out at $370 \mathrm{~nm}$, at which wavelength both pyrene derivatives absorb and phenanthrene excitation is negligible. Two aspects are

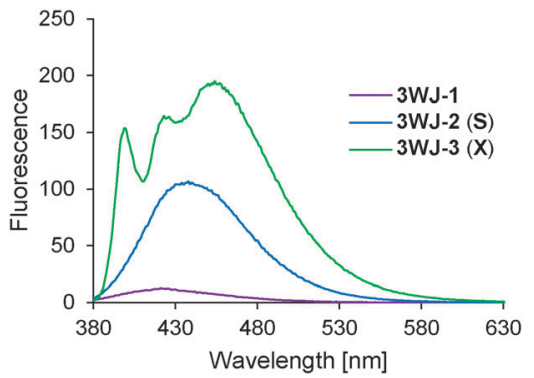

Fig. 3 Fluorescence spectra of 3 WJ-1, 3WJ-2 and 3WJ-3. Conditions: see Fig. 1. Instrumental set-up as in Fig. 2 (except for $\lambda_{\text {ex }}: 370 \mathrm{~nm}$ ).

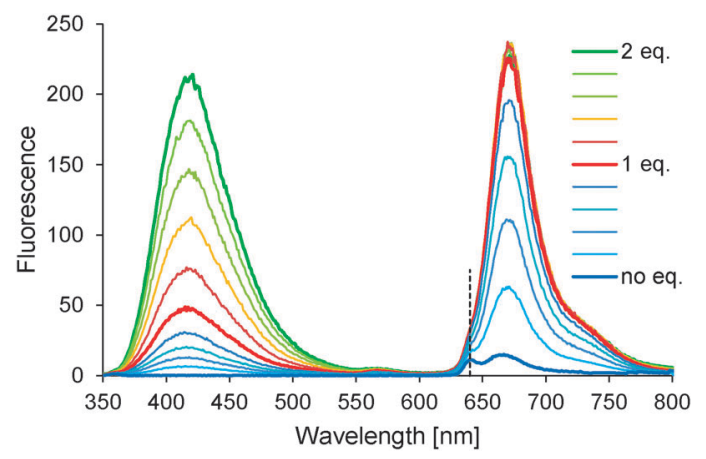

Fig. 4 Build-up of 3WJ-5: fluorescence spectra after stepwise addition of strands $\mathbf{a}$ and $\mathbf{b}$ (1:1-mixture) to single strand $\mathbf{g}$. The two strands were pre-annealed and added in 0.2 molar equivalents; an equilibration time of 5 minutes was given before recording the spectrum; other conditions were as shown in Fig. 2. Dashed marker indicates artefacts caused by the second order transmission of the monochromator.

worth noting: (i) the fluorescence intensities are significantly lower than that obtained after excitation of phenanthrene, which shows that the phenanthrene-pyrene $3 \mathrm{WJ}$ functions as a LHC; and (ii) the fraction of monomer emission in $\mathbf{3 W J}-\mathbf{3}$ is somewhat larger than after phenanthrene excitation ( $c f$. Fig. 2). Furthermore, direct excitation of control 3WJ-1 at $370 \mathrm{~nm}$ (Fig. 3) results in no significant fluorescence.

Energy transfer is also observed from phenanthrenes to Cy. Fig. 4 shows the effect of a stepwise build-up of 3WJ-5. In this experiment, the phenanthrene antenna (i.e. a 1:1-mixture of strands $\mathbf{a}$ and $\mathbf{b}$ ) is added stepwise to the acceptor dye (strand $\mathbf{g}$ ). A gradual increase in Cy fluorescence is observed until antenna and acceptor are present in equimolar concentrations. Phenanthrene excimer emission is also present and grows parallel to Cy fluorescence. Further addition of the antenna beyond the 1:1-ratio does not result in additional growth of Cy fluorescence, while phenanthrene fluorescence grows proportionally. The quantum yields for $\mathbf{P}$ and $\mathbf{C y}$ emission amount to 0.015 and 0.049 , respectively (Table 1). Cy has no significant absorbance (see ESI, $\uparrow$ Fig. S28) at the irradiation wavelength $(320 \mathrm{~nm})$ or in the region of phenanthrene emission (360-530 nm). As shown by the corresponding excitation spectra (Fig. 5), phenanthrene excitation $(320 \mathrm{~nm}$ ) leads to Cy emission only in 3WJ-5 but not in single strand $\mathbf{g}$. These experiments demonstrate that $\mathbf{C y}$ fluorescence in $3 \mathbf{W J}-5$ is due to energy transfer from the phenanthrenes. ${ }^{64}$ A Förster radius of $\sim 26 \AA$ is calculated (ESI $\dagger$ ). Considering the dimensions of the cavity in a typical $3 \mathrm{WJ}(\sim 12 \AA)^{65}$ as well as its inherent flexibility, ${ }^{33,65}$ energy transfer via FRET is, thus, possible. On the other hand, molecular contact between the donor and the acceptor is also 


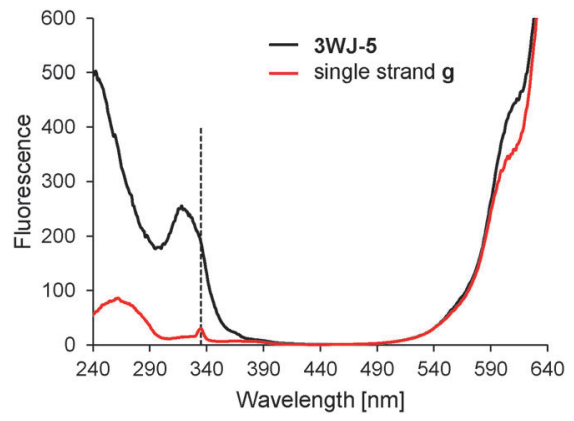

Fig. 5 Fluorescence excitation spectra of $\mathbf{3 W J}-\mathbf{5}$ and single strand $\mathbf{g}$ Conditions: Fig. 1; instrumental set-up: Fig. 2 , except for $\lambda_{\mathrm{em}}: 670 \mathrm{~nm}$; dashed marker: see Fig. 4.

feasible (as e.g. shown by exciplex formation in $3 \mathbf{W J}-2$ and -3 ) rendering excitation transfer via Dexter electron exchange a plausible mechanism. ${ }^{61,66}$

In conclusion, we have described the construction of LHCs on the basis of the DNA 3WJ. The LHC is based on a modular construction in which a phenanthrene antenna is located in one of the three stems and the acceptor is brought into proximity of the antenna through the annealing of the third strand. Phenanthrene excitation $(320 \mathrm{~nm})$ is followed by energy transfer to pyrene, perylenediimide or a cyanine dye. In the case of pyrene, exciplex fluorescence is observed, whereas perylenediimide acts as a quencher. In the case of cyanine, energy transfer leads to cyanine fluorescence. The study demonstrates the use of the DNA $3 \mathrm{WJ}$ for the modular assembly of artificial LHCs.

This work was supported by the Swiss National Foundation (Grant 200020-149148).

\section{Notes and references}

1 D. Gust, T. A. Moore and A. L. Moore, Acc. Chem. Res., 1993, 26, 198-205. 2 Light-Harvesting Antennas in Photosynthesis, ed. B. R. Green and W. W. Parson, Kluwer Acad. Publ., Dordrecht, 2003.

3 Artificial Photosynthesis - From Basic Biology to Industrial Applications, ed. A. F. Collings and C. Critchley, Wiley-VCH, Weinheim, 1st edn, 2005.

4 A. Hagfeldt and M. Graetzel, Acc. Chem. Res., 2000, 33, 269-277.

5 I. McConnell, G. H. Li and G. W. Brudvig, Chem. Biol., 2010, 17, 434-447. 6 S. E. Webber, Chem. Rev., 1990, 90, 1469-1482.

7 M. Graetzel, J. Photochem. Photobiol., C, 2003, 4, 145-153.

8 V. Balzani, A. Credi and M. Venturi, ChemSusChem, 2008, 1, 26-58.

9 A. C. Benniston and A. Harriman, Mater. Today, 2008, 11, 26-34.

10 B. C. Thompson and J. M. J. Frechet, Angew. Chem., Int. Ed., 2008, 47, 58-77.

11 M. R. Wasielewski, Acc. Chem. Res., 2009, 42, 1910-1921.

12 C. Li, M. Y. Liu, N. G. Pschirer, M. Baumgarten and K. Müllen, Chem. Rev., 2010, 110, 6817-6855.

13 G. Calzaferri, R. Meallet-Renault, D. Brühwiler, R. Pansu, I. Dolamic, T. Dienel, P. Adler, H. R. Li and A. Kunzmann, ChemPhysChem, 2011, 12, 580-594.

14 R. W. Wagner and J. S. Lindsey, J. Am. Chem. Soc., 1994, 116, 9759-9760. 15 S. Delahaye, C. Loosli, S. X. Liu, S. Decurtins, G. Labat, A. Neels, A. Loosli, T. R. Ward and A. Hauser, Adv. Funct. Mater., 2006, 16, 286-295.

16 N. Sakai, M. Lista, O. Kel, S. Sakurai, D. Emery, J. Mareda, E. Vauthey and S. Matile, J. Am. Chem. Soc., 2011, 133, 15224-15227.

17 V. Garg, G. Kodis, P. A. Liddell, Y. Terazono, T. A. Moore, A. L. Moore and D. Gust, J. Phys. Chem. B, 2013, 117, 11299-11308.

18 N. C. Seeman, Annu. Rev. Biochem., 2010, 79, 65-87.

19 C. K. McLaughlin, G. D. Hamblin and H. F. Sleiman, Chem. Soc. Rev., 2011, 40, 5647-5656.

20 M. Endo and H. Sugiyama, ChemBioChem, 2009, 10, 2420-2443.

21 M. A. Campbell and J. Wengel, Chem. Soc. Rev., 2011, 40, 5680-5689.

22 B. Sacca and C. M. Niemeyer, Angew. Chem., Int. Ed., 2012, 51, 58-66.

23 M. Famulok and G. Mayer, Acc. Chem. Res., 2011, 44, 1349-1358.
24 V. V. Filichev and E. B. Pedersen, in Wiley Encycl. Chem. Biol., 1, ed. T. P. Begley, Wiley, Hoboken, 2009, pp. 493-524.

25 R. Varghese and H. A. Wagenknecht, Chem. Commun., 2009, 2615-2624.

26 V. L. Malinovskii, D. Wenger and R. Häner, Chem. Soc. Rev., 2010, 39, 410-422.

27 T. J. Bandy, A. Brewer, J. R. Burns, G. Marth, T. Nguyen and E. Stulz, Chem. Soc. Rev., 2010, 40, 138-148.

28 E. Schwartz, S. Le Gac, J. J. L. M. Cornelissen, R. J. M. Nolte and A. E. Rowan, Chem. Soc. Rev., 2010, 39, 1576-1599.

29 H. Kashida and H. Asanuma, Phys. Chem. Chem. Phys., 2012, 14, 7196-7204.

30 Y. N. Teo and E. T. Kool, Chem. Rev., 2012, 112, 4221-4245.

31 M. E. Ostergaard and P. J. Hrdlicka, Chem. Soc. Rev., 2011, 40, 5771-5788.

32 C. Dohno and K. Nakatani, Chem. Soc. Rev., 2011, 40, 5718-5729.

33 D. M. J. Lilley, Q. Rev. Biophys., 2000, 33, 109-159.

34 M. H. Hansen, P. Blakskjaer, L. K. Petersen, T. H. Hansen, J. W. Hojfeldt, K. V. Gothelf and N. J. V. Hansen, J. Am. Chem. Soc., 2009, 131, 1322-1327.

35 I. T. Seemann, V. Singh, M. Azarkh, M. Drescher and J. S. Hartig, J. Am. Chem. Soc., 2011, 133, 4706-4709.

36 H. Xiong, P. Leonard and F. Seela, Bioconjugate Chem., 2012, 23, $856-870$.

37 M. Probst, D. Wenger, S. M. Biner and R. Häner, Org. Biomol. Chem., 2012, 10, 755-759.

38 J. L. Duprey, Y. Takezawa and M. Shionoya, Angew. Chem., Int. Ed., 2013, 52, 1212-1216.

39 W. Su, C. R. Bagshaw and G. A. Burley, Sci. Rep., 2013, 3, 1883, DOI: 10.1038/srep01883.

40 P. Kumar, K. I. Shaikh, A. S. Jorgensen, S. Kumar and P. Nielsen, J. Org. Chem., 2012, 77, 9562-9573.

41 O. Reinstein, M. A. Neves, M. Saad, S. N. Boodram, S. Lombardo, S. A. Beckham, J. Brouwer, G. F. Audette, P. Groves, M. C. Wilce and P. E. Johnson, Biochemistry, 2011, 50, 9368-9376.

42 L. Feng, C. Zhao, Y. Xiao, L. Wu, J. Ren and X. Qu, Chem. Commun., 2012, 48, 6900-6902.

43 O. N. Sancho, W. R. Browne and G. Roelfes, Chem.-Eur. J., 2013, 19, 2457-2461.

44 P. K. Dutta, R. Varghese, J. Nangreave, S. Lin, H. Yan and Y. Liu, J. Am. Chem. Soc., 2011, 133, 11985-11993.

45 B. Albinsson, J. K. Hannestad and K. Boerjesson, Coord. Chem. Rev., 2012, 256, 2399-2413.

46 F. Garo and R. Häner, Angew. Chem., Int. Ed., 2012, 51, 916-919.

47 O. O. Adeyemi, V. L. Malinovskii, S. M. Biner, G. Calzaferri and R. Häner, Chem. Commun., 2012, 48, 9589-9591.

48 J. G. Woller, J. K. Hannestad and B. Albinsson, J. Am. Chem. Soc., 2013, 135, 2759-2768.

49 C. M. Spillmann, M. G. Ancona, S. Buckhout-White, W. R. Algar, M. H. Stewart, K. Susumu, A. L. Huston, E. R. Goldman and I. L. Medintz, ACS Nano, 2013, 7, 7101-7118.

50 Charge Transfer in DNA - From Mechanism to Application, ed. H. A. Wagenknecht, Wiley-VCH, Weinheim, Germany, 2005.

51 C. V. Kumar and M. Duff, J. Am. Chem. Soc., 2009, 131, 16024-16026.

52 S. M. Langenegger and R. Häner, ChemBioChem, 2005, 6, 848-851.

53 S. M. Langenegger and R. Häner, Chem. Commun., 2004, 2792-2793.

54 H. Bittermann, D. Siegemund, V. L. Malinovskii and R. Häner, J. Am. Chem. Soc., 2008, 130, 15285-15287.

55 N. Rahe, C. Rinn and T. Carell, Chem. Commun., 2003, 2119-2121.

56 The slight differences are attributed to changes in the linkers, i.e. carboxamide $v s$. alkynyl-substituents.

57 Y. Nakamura, T. Yamazaki and J. Nishimura, Org. Lett., 2005, 7, 3259-3262.

58 F. D. Lewis and E. L. Burch, J. Photochem. Photobiol., A, 1996, 96, 19-23.

59 J. B. Birks, in The Exciplex, ed. M. Gordon and W. R. Ware, Academic Press Inc., New York, 1975, pp. 39-73.

60 F. M. Winnik, Chem. Rev., 1993, 93, 587-614.

61 P. Ceroni and V. Balzani, in The Exploration of Supramolecular Systems and Nanostructures by Photochemical Techniques, 78, ed. P. Ceroni, Springer, 2012, pp. 21-38.

62 J. R. Lakowicz, Principles of Fluorescence Spectroscopy, Springer, Singapore, 3rd edn 2006.

63 N. Bouquin, V. L. Malinovskii and R. Häner, Chem. Commun., 2008, 1974-1976.

64 D. Pevenage, M. Van der Auweraer and F. C. De Schryver, Chem. Phys. Lett., 2000, 319, 512-520.

65 T. Sabir, A. Toulmin, L. Ma, A. C. Jones, P. McGlynn, G. F. Schröder and S. W. Magennis, J. Am. Chem. Soc., 2012, 134, 6280-6285.

66 D. L. Dexter, J. Chem. Phys., 1953, 21, 836-850. 